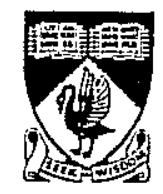

EMPIRICAL STUDIES OF SELF-EMPLOYMENT

by

A.T. Le

DISCUSSION PAPER 98.11

DEPARTMENT OF ECONOMICS

THE UNIVERSITY OF WESTERN AUSTRALIA

NEDLANDS, WESTERN AUSTRALIA 6907 


\title{
EMPIRICAL STUDIES OF SELF-EMPLOYMENT
}

\author{
by \\ A.T. Le \\ Department of Economics \\ The University of Western Australia
}

DISCUSSION PAPER 98.11

DEPARTMENT OF EOCNOMICS

THE UNIVERSITY OF WESTERN AUSTRALIA

NEDLANDS, WESTERN AUSTRALIA 6907

ISSN 0811-6067

ISBN 0-86422-852-X

I wish to thank Paul Miller, Charles Mulvey and two anonymous referees for helpful comments. 


\title{
EMPIRICAL STUDIES OF SELF-EMPLOYMENT
}

\begin{abstract}
This paper presents a review of empirical studies of self-employment for the Australian, Canadian, Dutch, U.K. and U.S. labour markets. Both cross-sectional and longitudinal studies are analysed. Analyses using cross-sectional data examine the propensity to be self-employed at any one point in time, whereas longitudinal studies focus on the transition into self-employment from wage/salary employment and the survival rate in this state over time. Various hypotheses advanced in the economics and sociology literatures on self-employment are tested. These include the relationship between managerial ability and the propensity to be self-employed and the impact of financial constraints on entry into self-employment stressed in economic models of entrepreneurship, and the relationships between self-employment choice and the nature of the work and group characteristics (e.g., ethnic enclaves) stressed in sociological models of entrepreneurship. The evidence shows that self-employment outcomes are significantly affected by factors such as individual abilities, family background, occupational status, liquidity constraints and ethnic enclaves.
\end{abstract}




\section{EMPIRICAL STUDIES OF SELF-EMPLOYMENT}

\section{Introduction}

The allocation of the paid labour force between self-employment and wage/salary employment has emerged as an important aspect of the labour market in recent years. The self-employed have become an important class of worker in many developed countries, accounting for 16 percent of the paid workforce in Australia, 10 percent in Canada, 13 percent in the U.K. and 9 percent in the U.S.. Government programmes have been introduced to encourage this employment status as a number of countries (e.g., Australia, U.K. and U.S.) have looked to self-employment as a possible solution to their unemployment and poverty problems. For example, in Australia a programme called the New Enterprise Incentive Scheme has provided training and income support to the unemployed who wish to enter into self-employment. In the U.K. the government provides transfer payments to the unemployed while they start their business. Encouragement of minority small businesses also exists in the U.S., where the government has set up programmes for that particular purpose.

The self-employed are held to have greater autonomy in employment, and may have a greater socioeconomic status. Therefore, determining which workers enter into selfemployment is important to understanding economic well being. Self-employment may also play a role in the immigrant-adjustment process, a factor that will be an important consideration in major immigrant receiving countries like the U.S., Canada and Australia. For these reasons the number of academic studies of self-employment has increased in recent years. The emergence of interest in self-employment is evident in both the economics and sociology literatures, and in studies of a theoretical and of an empirical nature. From the theoretical perspective, the roles of attitudes towards risk, entrepreneurial ability, taxation, uncertainty and capital requirements have been studied. Models encompassing these themes are reviewed by de Wit (1993a, 1993b). He explains the workings of the models and provides a useful basis for study of the number of self- 
employed in the labour market. Applying the theoretical models, de Wit provides a brief introduction to the empirical literature.

The aim of this paper is to provide a detailed review of the empirical literature on selfemployment. The review is organised in the following way. The next section provides information on the way the self-employed are categorised in official statistics and compares the importance of self-employment across countries. Section 3 focuses on crosssectional analyses of the propensity to be self-employed. The results from both reducedform and structural equations are presented. Following this, results from longitudinal analyses regarding the transition into and out of self-employment are reported in Section 4. A summary and conclusion are presented in the fifth section.

\section{Definition of Self-Employment and Cross-Country Comparisons}

The definition of self-employment varies slightly across data sets and countries. The OECD, for example, categorises the employed into paid employment, self-employment and unpaid employment. Self-employment is defined as individuals who perform some work for profit or family gain, in cash or in kind. Included in this category are employers, own account workers and persons in production of goods/services and household consumption. The $\amalg O$ and UN publish data on several employment categories, including employee, unpaid family helpers, employer and own account workers. An employer is a person who operates his/her own economic enterprise or engages independently in a profession/trade and hires one or more employees. An own account worker is a person who operates his/her own economic enterprise or engages independently in a profession/trade and hires no employees. The employer and own account worker groups can be aggregated to give the total number of self-employed.

Most of the studies reviewed in this paper are based on official data sets where the definition of self-employment is similar to that adopted by the ILO. Where data sets have reference to the legal status of the business (incorporated, unincorporated) this distinction 
has not been used in empirical work. While there does not appear to have been any study of whether definitions affect the comparability of self-employment statistics, the similarity of the wording in various data sets suggests there should be a broad degree of comparability. ${ }^{1}$

To compare the importance of self-employment across countries, Table 1 presents timeseries data on the proportion of paid employment (includes wage/salary employed and self-employed) accounted for by self-employment. ${ }^{2}$ The data from this table show some interesting patterns of self-employment across countries that can be illustrated by using the Australian experience as a benchmark. First, it appears that rates of self-employment in the developing or economically 'poor' countries in Asia are higher than in Australia. For example, the self-employment rates in Malaysia, the Philippines and Sri-Lanka are relatively high compared to Australia. In particular, the self-employment rate in the Philippines is more than double Australia's self-employment rate of 16.04 percent in 1993. To the extent that these countries are economically 'poor' compared to Australia, their relatively high self-employment rates suggest that workers in these countries may view self-employment as a solution to their poverty problem. In comparison, most European (e.g., Denmark, Norway, Sweden, the U.K.) and North American (e.g., Canada, U.S.) labour markets have rates of self-employment lower than those in the Australian labour market. Australia's situation as a high self-employment, developed country may be due to characteristics of the workforce (e.g., a relatively high fraction of the workforce in Australia is foreign born), or due to regional considerations (the size of the country may

1 For example, the definition of self-employment available from the U.S. Census is "working in own not incorporated or incorporated business, professional practice or farm". The Census of Canada disaggregates the self-employed into "incorporated, unincorporated without paid help and unincorporated with paid help".

2 For all countries, the percentage of the workforce which is self-employed is calculated by summing the total number of self-employed persons and dividing this by the total number in paid employment (employee and self-employed). It should be noted that in some cases data are obtained from different sources for each country and across countries (see Table 1 notes). However, given that the definitions of self-employment are similar across the sources mentioned, the figures from Table 1 should be appropriate to use for cross-countries comparisons. 
increase the importance of local markets which favour small local businesses over large national businesses).

Table 1: Self-Employment Rates from 1970-1994, by Country

\begin{tabular}{|c|c|c|c|c|c|c|c|c|}
\hline \multirow[t]{2}{*}{ Country } & \multicolumn{8}{|c|}{ Year (Estimates of the average for the year, Percent) } \\
\hline & 1970 & 1975 & 1980 & 1985 & 1990 & 1991 & 1992 & 1993 \\
\hline \multicolumn{9}{|l|}{ Europe } \\
\hline Belgium & 15.24 & 13.62 & 13.58 & 14.62 & nа & 14.87 & na & па \\
\hline Denmark & 16.12 & 14.54 & па & 10.17 & na & na & па & 8.45 \\
\hline France & 21.58 & 18.23 & 16.79 & 15.99 & 14.33 & 14.02 & na & 11.96 \\
\hline Germany $^{a}$ & 11.01 & 10.22 & 9.50 & 10.31 & na & па & 8.48 & 8.54 \\
\hline Greece & na & па & 50.30 & 42.16 & na & 38.76 & 38.68 & na \\
\hline Italy & 32.57 & 29.26 & 27.41 & 29.35 & па & na & $\mathrm{na}$ & $\mathrm{na}$ \\
\hline Norway & 18.22 & 11.79 & 10.28 & 9.78 & $7.86^{\mathrm{b}}$ & na & $\mathrm{na}$ & 8.96 \\
\hline Sweden & 9.01 & 7.26 & na & na & 6.57 & 8.58 & 9.21 & 10.37 \\
\hline U.K. ${ }^{\varepsilon}$ & 7.80 & 8.07 & 8.06 & 10.82 & 12.24 & 12.06 & па & 12.71 \\
\hline Australia & 13.31 & 13.88 & 16.22 & 16.00 & 15.02 & 14.73 & 15.71 & 16.04 \\
\hline \multicolumn{9}{|l|}{ Asia } \\
\hline Hong Kong & па & na & na & $10.97^{d}$ & na & $11.13^{b}$ & па & 10.60 \\
\hline Indonesia & na & na & па & na & па & 56.34 & 60.13 & na \\
\hline Japan & ma & na & na & $16.94^{\mathrm{h}}$ & 14.59 & 14.59 & 14.14 & 13.53 \\
\hline Malaysia & па & na & na & na & 26.35 & па & па & 22.83 \\
\hline Philippines & $\mathrm{na}$ & па & na & na & na & na & na & 46.43 \\
\hline Sri-Lanka & na & na & กа & na & $\mathrm{na}$ & па & па & 30.67 \\
\hline \multicolumn{9}{|c|}{ North America } \\
\hline Canada & 11.55 & 8.49 & 8.83 & 9.65 & 8.78 & 8.93 & 9.07 & 9.72 \\
\hline U.S. & 9.05 & 8.74 & 8.77 & 8.69 & 8.25 & 8.41 & 8.04 & 8.23 \\
\hline
\end{tabular}

Note: ${ }^{a}$ These figures relate to the former Federal Republic of Germany. ${ }^{b}$ These figures are from the censuses of respective countries. ${ }^{c}$ The figures are mid-year estimates. ${ }^{d}$ The figure relates to 1986 . na $=$ Not available.

- Data for European countries for the period 1970-86 are obtained from OECD publications, and for the period 1987-93 they are obtained from ILO publications.

- Data for Asian countries for the period 1987-93 are obtained from $\mathrm{LO}$ and UN publications.

- Data for North American countries for the period 1970-86 are obtained from OECD publications, and for the period 1987-93 they are obtained from ILO publications.

Source: Intemational Labour Office $(1994,1995)$; OECD, Department of Economics and Statistics (1988); United Nations, Department for Economics and Social Information and Policy Analysis (1996).

Self-employment, therefore, is an important sector of the labour market of all countries. The studies reviewed below provide information on the factors that affect the allocation of workers to self-employment and their survival in this sector. 


\section{Cross-Sectional Analyses}

Cross-sectional studies of self-employment have been of two broad types. The majority have been based on reduced-form models. A small number, however, have been based on the estimation of a structural model. While the structural approach has the potential to provide a richer array of insights into the determinants of self-employment choice, there are several practical problems with this type of study. These problems, which are discussed below, appear to affect the reliability of the findings. Accordingly, as the results obtained from the reduced-form models are more robust they are covered in greater detail in this survey.

\subsection{The Reduced-Form Self-Employment Equation}

Most studies of self-employment have been based on a reduced-form equation. Examples include Evans (1989) and Kidd (1993) for the Australian labour market, Blanchflower and Oswald (1990) for the U.K. labour market, and Borjas (1986), Brock and Evans (1986), Borjas and Bronars (1989) and Evans and Leighton $(1989)^{3}$ for the U.S. labour market. In addition, a reduced-form model has been estimated as part of the structural equations approach adopted by Bernhardt (1994) for the Canadian labour market, de Wit and van Winden (1989) and de Wit (1993) for the Dutch labour market ${ }^{4}$ and Rees and Shah (1986) for the U.K. labour market. These studies primarily focus on males aged 16-64. Evans focused on foreign-born men, Bernhardt's study pertained to White Canadian males and Borjas and Bronars' study focused on White, Black, Asian and Hispanic native and foreign-born males. The other studies generally cover both the native born and overseas born in the 16-64 year age bracket. However, two studies, namely Borjas and Bronars and Blanchflower and Oswald, focused on the age groups 25-64 and less than 23 years respectively.

3 Evans and Leighton (1989) used longitudinal data. To report cross-sectional estimates of the probability of being self-employed, the authors estimated on a sample of individuals who were employed in 1981.

4 Although de Wit and van Winden (1989) and de Wit (1993) used longitudinal data, the models they estimated are static. Hence, it is appropriate to compare the results from these studies to those which used cross-sectional data. 
The definitions of categories of employment in the data sets analysed are comparable, and permit the definition of a self-employed worker as one who works for himself/herself (in an incorporated or unincorporated business) and who may or may not have paid help. However, it should be noted that particular groups are excluded from the estimating samples in a number of studies. For example, Borjas (1986), Brock and Evans (1986), Rees and Shah (1986), Blau (1987), Borjas and Bronars (1989) and Bernhardt (1994) exclude the agricultural sector from their definition of self-employment. Moreover, Brock and Evans (1986) and Bernhardt (1994) exclude from the analysis professionals (e.g., doctors, dentists, lawyers, veterinarians or other health professionals), part-time selfemployed persons and commission salesmen. These exclusions are made mainly in order to focus on situations where workers are likely to face the choice between selfemployment and wage/salary employment depicted in models of self-employment. Evans (1989) excludes individuals who own their business but do not hire employees. This allows her to focus on self-employed immigrants who are able to take advantage of the cheap source of ethnic labour in the enclave markets.

Most studies have as their primary aim an examination of the range of potential determinants of self-employment choice. There are, however, particular issues that are examined in several studies. For example, the focus of the study by de Wit and van Winden (1989) is the impact of family background and an individual's IQ on entrepreneurship. In Borjas' (1986) study the focus is on factors (e.g., immigrant adjustment in the local labour market) causing the immigrant/native-born differential in the propensity to be self-employed. Borjas and Bomars (1989) examine the impact of race and discrimination on the propensity to be self-employed. Evans (1989) has an examination of the roles of ethnic enclaves in promoting self-employment among immigrants as a key feature of her study, while Rees and Shah (1986) and Bernhardt (1994) both examine reduced-form equations as part of a wider analysis that focuses on the links between the earnings differential between self-employment and wage/salary employment and selfemployment choice. 
To examine these issues, the general reduced-form equation of self-employment choice $\left(S E_{j}^{*}\right)$ used in the literature may be expressed as:

$$
S E_{j}^{*}=X_{j} \beta+v_{j}
$$

where the vector $X_{j}$ contains the 'traditional' variables of education, labour market experience, age, job stability, capital, occupational status, unemployment, location, marital status, spouse's educational attainment, spouse's employment status, the number of children and health status. In addition, family background variables, such as the employment status and occupation of the father, are also sometimes included. Other variables which are considered in only a few empirical studies include psychological characteristics of the individuals and group characteristics such as the role of ethnic enclaves (e.g., Borjas (1986) and Evans (1989)). The reduced-form model is generally estimated using either a logit or probit approach. Given that the dependent variable in the studies is binary (usually defined so that the self-employed category equals 1 and the wage/salary employed equals 0 ) these methods are appropriate. Few diagnostics other than for pseudo R-squareds (see Veall and Zimmermann (1996)) or other general goodness-offit measures are presented. The main specification issue raised is the simultaneous determination of employment status and earnings. Details are presented in Section 3.2.

This equation has also been estimated separately for the native bom and immigrants. When the focus of attention is on immigrants, variables such as period of residence and English-speaking ability are also included in the vector of observable characteristics. Differences in the impacts of characteristics on the employment status of various birthplace groups are a focus of much of the literature.

The empirical results from studies adopting a reduced-form approach are reviewed below in eight subsections relating to the effects on self-employment choice of: i) Educational Attainment and General Intelligence, ii) Labour Market Experience, iii) Other Individual 
and Family Background Characteristics, iv) Economic Conditions, v) Financial Capital, vi) Occupational Status, vii) Race, and viii) Group Characteristics.

\section{Educational Attainment and General Intelligence}

One of the major theoretical determinants of self-employment choice is educational attainment. There are several channels through which the level of education might influence the propensity to become self-employed. On the one hand, the impact of educational attainment on self-employment choice can be explained using Lucas' (1978) model. In this model education enhances an individual's managerial ability and hence increases the propensity to be self-employed. On the other hand, it is possible that a higher level of education may facilitate entry into the wage/salary sector and thus depress the likelihood of business ownership. The net impact of the offsetting influences of the level of education on the propensity to be self-employed cannot be determined a priori, and this appears to be reflected in the conflicting evidence from empirical studies.

From Table 2, studies by Rees and Shah (1986), Borjas (1986), Borjas and Bronars (1989) - and Evans and Leighton (1989) suggest that a more educated person has a higher probability than a less-well educated person of choosing self-employment. In contrast, Evans (1989), de Wit and van Winden (1989), de Wit (1993) and Kidd (1993) report that a high level of education deters entry into self-employment. Some of the differences between these studies may arise because of differences in the specification of the estimating equations. For example, unlike other studies, Evans (1989) controlled for occupational status, a variable that is positively correlated with both educational attainment and the propensity to be self-employed. This implies that the omitted variables bias in the education coefficient in studies that do not control for occupational status will be positive. It is not surprising, therefore, that studies that do not control for occupational status generally report a positive (or weak negative) relationship between the self-employment propensity and education whereas this relationship is negative and statistically significant when such a control is implemented, such as in the studies by Evans (1989), de Wit and 
van Winden (1989) and de Wit (1993). ${ }^{5}$

The impacts of educational attainment on the propensity to be self-employed may not be the same for all groups of workers. This issue has been examined with reference to the native born and immigrants in several studies. Kidd (1993), for example, reported that among the Australian born, compared to those who did not complete year 10, individuals who possess a diploma are 3.87 percentage points less likely to be self-employed. ${ }^{6}$ Within the immigrant sample, different levels of education do not significantly influence the propensity to be self-employed. There are several explanations for this result. If selfemployment is the superior alternative it implies that immigrant skills are transferable across countries, which would be contrary to the immigrant wage adjustment literature. However, if wage/salary employment is the superior altemative, the finding suggests that self-employment may be a refuge for better educated immigrants whose foreign qualifications are not recognised in the destination labour market. The possibility that selfemployment can be a refuge for individuals who experience employment difficulties in the wage/salary sector is emphasised in a number of studies (e.g., Rees and Shah (1986), - Evans and Leighton (1989)).

5 de Wit and van Winden (1989) and de Wit (1993) actually control for several sectors such as agriculture, trade, hotel and repairs.

6 This partial effect is an approximation calculated by the author as follows. Let the mean rate of selfemployment be $S \bar{E}$. Then we assume $S \bar{E} \approx \Phi(I)$, hence $I=\Phi^{-l}(S \bar{E})$. It is this value of $I$ that is used in the computations of the $k^{\text {hh }}$ partial effect given by $\phi(I) \hat{\beta}_{k}$. Where partial effects have not been presented in particular studies they have been computed in this manner. 
Table 2: Individual Qualities and Self-Employment Propensity

\begin{tabular}{|c|c|c|c|c|c|c|c|c|c|c|c|c|c|c|c|c|c|}
\hline Studly ${ }^{\dagger}$ & \multicolumn{5}{|c|}{ Borjas $(1986)^{x^{*}}$} & . & Rees \& & \multicolumn{4}{|c|}{ Borjas \& Bronars (1989)* } & \multirow{2}{*}{$\begin{array}{c}\text { Evans } \\
(1989)^{4}\end{array}$} & \multirow{2}{*}{$\begin{array}{c}\text { Evans \& } \\
\text { Leighton } \\
(1989)\end{array}$} & de Wit & \multicolumn{2}{|c|}{ Kidd (1993) } & \multirow{2}{*}{$\begin{array}{c}\text { de Wit } \\
(1993) \\
\text { Total }\end{array}$} \\
\hline Sample & White & Blick & Asinn & Mexican & Cuban & $\begin{array}{c}\text { Other } \\
\text { Hispanic }\end{array}$ & Total & While & Black & Asian & Hispanic & & & Total & Native & Migrant & \\
\hline \multicolumn{18}{|l|}{ Vuriable } \\
\hline \multicolumn{18}{|l|}{ Education } \\
\hline$\frac{\text { Continuous }}{\text { Edu (yrs) }}$ & $.039^{\circ}$ & $.041^{\circ}$ & $.043^{\circ}$ & $.052^{\circ}$ & $.030^{\circ}$ & $.070^{\circ}$ & $2.182^{\circ}$ & & & & & $-.068^{\circ}$ & $.047^{\circ}$ & $-.023^{\circ}$ & & & $-.026^{\circ}$ \\
\hline \multicolumn{18}{|l|}{ Ciltegorical } \\
\hline$<12$ yrs & & & & & & & & $-.074^{b}$ & .039 & -.016 & -.114 & & & & & & \\
\hline $12 \mathrm{yrs}$ & & & & & & & & -.060 & -.034 & -.007 & -.026 & & & & & & \\
\hline Grade 10 & & & & & & & & & & & & & & & $-.045^{*}$ & -.012 & \\
\hline Secondary & & & & & & & & & & & & & & & -.033 & .153 & \\
\hline Trade & & & & & & & & & & & & & & & .032 & .094 & \\
\hline $\begin{array}{l}\text { Diplomil } \\
\text { Degree }\end{array}$ & & & & & & & & & & & & & & & -.064 & $\begin{array}{l}.030 \\
-.014\end{array}$ & \\
\hline Edu: Aust & & & & & & & & & & & & $.027^{4}$ & & & & & \\
\hline Intelligence & & & & & & & & & & & & & & & & & \\
\hline IQ score & & & & & & & & & & & & & & $.840^{\circ t}$ & & & $.720^{\circ}$ \\
\hline Scholar score & & & & & & & & & & & & & & .005 & & & -.010 \\
\hline
\end{tabular}

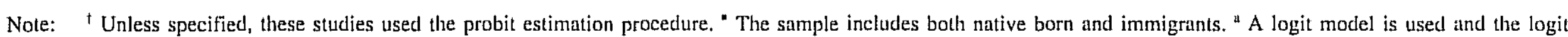
coefficients have been multiplied by 0.625 for comparability with the probit coefficients. "The omitted category is those with $13-15$ years of education. "The omitted category is those who did not complete year $10 .{ }^{\text {" }}$ The omitted category is those who had obtained their education in their country of origin. ${ }^{\mathrm{E}}$ Education $=$ Edu/100. 'IQ-score $=\mathrm{IQ} / 100$. 'The estimated coefficients are statistically significant at the 10 percent level or higher. Edu $=$ years of education; Edu:Aust $=$ education acquired in Australia. 
A second variable which measures individual ability is general intelligence. It may be the case that individuals with a relatively high level of intelligence possess sufficient managerial skills to enter into self-employment. To test Lucas' (1978) hypothesis that there are positive links between ability and entrepreneurship, de Wit and van Winden (1989) and de Wit (1993) included an IQ-score and a scholastic test score (scale 0-10) in their estimating equation. ${ }^{7}$ The results from both studies indicated that the IQ-score, computed at the age of 12 , has a positive influence on the self-employment probability whereas the coefficient on the scholastic test score is insignificant (Table 2). This indicates that the more general factors (see footnote 7) captured by the IQ test are more important to the self-employment decision.

These results indicate, therefore, that education and general intelligence variables have mixed performances in equations determining self-employment. This may suggest either that managerial ability is not a major determinant of the self-employment decision, or that its influence is more appropriately captured using other variables such as experience accumulated in the labour market.

\section{Labour Market Experience}

Labour market experience ${ }^{8}$ is viewed here as an index of the accumulated general knowledge that enables an individual to understand the workings of the labour and product markets. As such it provides an alternative means of testing the hypotheses of Lucas (1978) and Calvo and Wellisz (1980) that greater managerial and learning abilities will be associated with higher levels of entrepreneurship. Because there is a focus on knowledge of the working of the labour market rather than the more academic-oriented knowledge

7 The IQ-score in the standard test comprises six sub-tests relating to numbers, words, analogies and spatial orientation. The scholastic test score is calculated as the mean score on eight tests, namely history, biology, arithmetic, reading, verbal proficiency and word tests.

8 In most cases, a direct measure of years of experience is not available and an indirect measure is used. Researchers use either the individual's age as a proxy for labour market experience, or labour market experience is computed from information on the individual's age and years of education (age - years of education - 5). 
reflected in measures of formal education, labour market experience can be viewed as a better variable for the testing of hypotheses advanced in the self-employment literature. The empirical evidence appears to support the proposition that workforce experience has a positive effect on the propensity to be self-employed (see Table 3). For example, in the U.S., Borjas (1986) reported that self-employment probabilities increase with potential labour market experience for all racial groups other than for Blacks. It should be noted, however, that there are other possible interpretations of the self-employment effects associated with labour market experience. For example, it has been argued that as labour market experience lengthens, an individual is able to accumulate the financial resources necessary for successful entrance into self-employment, and this financial capital factor, rather than human capital factors, explains the empirical regularity of Table 3 . As the relationship between labour market experience and the propensity to be self-employed is not statistically significant in the study by Bernhardt (1994) that controls for financial capital, this alternative explanation might be preferred. ${ }^{9}$

Similar to the treatment of the effects of education by applied researchers, the effects of labour market experience on the propensity to be self-employed may differ depending on where the experience was obtained. It is expected that labour market experience obtained by immigrants in the country of destination would have a stronger influence on the propensity to be self-employed than experience obtained in the country of origin. This is likely to reflect the non-transferability internationally of skill/knowledge. Some labour market knowledge, such as of the wage and enterprise bargaining system and work ethics, is country-specific and hence would be lost through migration. Knowledge of product markets may similarly be lost through migration. It is expected that the extent of the loss would be greater in the case of the country-specific knowledge relevant to selfemployment (e.g., knowledge of the bureaucracy and red tape). These aspects of the relationship between experience and self-employment outcomes can be captured either by

9 As a general issue, it is apparent that testing of models of self-employment using data sets that contain information on financial capital is an area requiring further research. 
constructing separate variables for experience obtained abroad and in the country of destination, or by including information on period of residence in a model that includes a total labour market experience variable. ${ }^{10}$ The one study that has used the former approach is Evans (1989). She reports that immigrants who have accumulated more Australian labour force experience have a higher level of entrepreneurship than those who obtained most of their labour force experience overseas (see Table 3).

The effect of period of residence on employment choice is analysed by Evans (1984), Borjas and Bronars (1989) and Kidd (1993). Period of residence could increase the probability of self-employment for a number of reasons. Firstly, as mentioned above, this effect may be associated with knowledge of the local market and customs (Evans (1989)). A native-born person would have an advantage over recently arrived immigrants regarding labour market knowledge of the host country. This advantage would be expected to diminish the longer the immigrant has lived in the host country. Secondly, some immigrants might enter the host country with limited capital, and duration of residence allows capital to be accumulated, thereby providing them with the resources to enter into self-employment (Borjas (1986), Kidd (1993)). Thirdly, the longer an immigrant resides in the host country, the greater the opportunity that person would have had to access labour supplies and equipment. In addition, the person would have had more time to assess the tastes and preferences of the ethnic customers. 
Table 3: Labour Market Experience, Period of Residence and Self-Employment Propensity

\begin{tabular}{|c|c|c|c|c|c|c|c|c|c|c|c|c|c|c|c|c|c|c|c|c|}
\hline \multirow{2}{*}{$\begin{array}{l}\text { Study } \\
\\
\text { Sumple }\end{array}$} & \multirow{2}{*}{$\begin{array}{l}\text { Evans } \\
\text { (198-1)' } \\
\text { Migraut } \\
\text { (7Tirt } \\
\text { World) }\end{array}$} & \multicolumn{6}{|c|}{ BurJas (1986)" } & \multirow{2}{*}{$\begin{array}{c}\text { Ilrock } \\
\& \\
\text { Evans } \\
\text { (19y86) } \\
\text { Totul }\end{array}$} & \multirow{2}{*}{$\begin{array}{c}\text { Rees \& } \\
\text { Stunh } \\
\text { (11986) }\end{array}$} & \multicolumn{4}{|c|}{ Borjas \& Bronurs (1989)' } & \multirow{2}{*}{$\begin{array}{l}\text { Evans } \\
(1984)^{2}\end{array}$} & \multirow{2}{*}{$\begin{array}{c}\begin{array}{c}\text { Evans \& } \\
\text { Leighitun } \\
\text { (1989) }\end{array} \\
\text { Total }\end{array}$} & \multirow{2}{*}{$\begin{array}{c}\text { de Wii } \\
\& \text { van } \\
\text { Winden } \\
\text { (19B9) } \\
\text { Totul }\end{array}$} & \multicolumn{3}{|c|}{ Khid (19y3) } & \multirow{2}{*}{$\begin{array}{c}\text { de } \\
\text { Wit } \\
(19 y 3)\end{array}$} \\
\hline & & White & Black & Asians & Mexleun & Cuban & $\begin{array}{c}\text { Olher } \\
\text { Ilispante }\end{array}$ & & & White & Bluck & Asian & Ilispanic & & & & Migrant & ES & NES & \\
\hline \multicolumn{21}{|l|}{ Vurluble } \\
\hline Exp (yrs) & & $.022^{\circ}$ & .014 & $.033^{\circ}$ & $.034^{\circ}$ & $.029^{\circ}$ & $.022^{\circ}$ & & & & & & & & $.063^{* 4}$ & & & & & .040 \\
\hline $\operatorname{Exp}^{2}(y r s)$ & & $-.00004^{\circ}$ & .0000 & $-.00 \times 13^{\circ}$ &. $.00006^{\circ}$ & $.00007^{\circ}$ & $-.0 \times 013^{*}$ & & & & & & & & & & & & & $-.170^{*}$ \\
\hline Exp (yrs) Aust & & & & & & & & & & & & & & $.016^{\circ}$ & & & & & & \\
\hline $\operatorname{Exp}(y r s) O / S$ & & & & & & & & & & & & & & $-014^{4}$ & & & & & & \\
\hline Age (yrs) & & & & & & & & $.550^{\circ}$ & 5.8. $81^{4}$ & $.061^{\circ}$ & $.083^{\circ}$ & $.082^{\circ}$ & $.087^{\circ}$ & & & & $.100^{\circ}$ & $-.123^{\circ}$ & $-.078^{*}$ & \\
\hline $\mathrm{Age}^{2}(\mathrm{yrs})$ & & & & & & & & $.04 \mathrm{~B}^{4}$ & $-6.316^{.4}$ & $.0011^{\circ}$ &.$(00)^{\circ}$ & $-(x) 1^{\circ}$ &.$\left(0011^{\circ}\right.$ & & & & $-.0011^{\circ}$ & $-.0001^{\circ}$ &.$\left(001^{\circ}\right.$ & \\
\hline Resi (yrs) & $.4+40^{\prime} 8$ & & & & & & & & & .018 & $.00 \mathrm{H}$ & $.024^{\circ}$ & $.020^{\circ}$ & & & & $.013^{\circ}$ & -.013 & $.042^{\circ}$ & \\
\hline $\operatorname{Resi}^{2}(\mathrm{yrs})$ & & & & & & & & & & .0003 & $.0 \times 03$ & -.00003 & .00003 & & & & -.000001 & $.00 x) 4^{*}$ & $.0 \times 066^{\circ}$ & \\
\hline
\end{tabular}

Note: $t^{*}$ " See Table 2. " The second order term for experience was not statistically significant and therefore was not reported by Evans and Leighton (1989). ${ }^{\mathrm{c}}$ Age $=$ Age/10; $\mathrm{Age}^{2}=\mathrm{Age} / 100 .{ }^{4} \mathrm{Age}=\mathrm{Age} / 100 ; \mathrm{Age}^{2}=\mathrm{Age}^{2} / 1,000 .{ }^{\circ} \operatorname{Exp}^{2}=\operatorname{Exp}^{2} / 100 .{ }^{\mathrm{C}}$ The coefficient is derived using a Metric Regression Approach. ${ }^{\text {s }}$ The coefficient refers to female immigrants. $\mathrm{ES}=$ English-speaking; $\operatorname{Exp}=$ years of labour market experience; Exp $(\mathrm{O} / \mathrm{S})=$ labour market experience acquired overseas; $\operatorname{Exp}($ Aust $)=$ labour market experience acquired in Australia; NES = Non-English speaking; Resi = period of residence in the country of destination. 
All of the theoretical period of residence effects discussed above act in the same direction and it might therefore be expected that clear patterns would emerge from applied research. However, the empirical evidence on the relationship between period of residence and the self-employment probability is ambiguous (see Table 3). For example, with regard to Australian studies, Evans (1984) found, in general, that period of residence does not significantly influence the propensity to be self-employed of all female Australian immigrants. The only group for which years in Australia has a significant effect is immigrants from the Third World. This may be due to these immigrants possessing relatively little capital when they arrive in Australia. Kidd (1993) reported that period of residence is a significant determinant of the propensity to be self-employed for male immigrants as a whole. However, this influence differs for the English-speaking and nonEnglish speaking groups, with the impact of duration of residence in Australia being significant only for the latter group. In particular, Kidd found that the propensity to be self-employed of non-English speaking immigrants increases at a decreasing rate with duration of residence."

For the U.S. Iabour force, Borjas and Bronars (1989) found that the relationship between period of residence and the propensity to be self-employed is only significant for two (Asian and Hispanics) out of four immigrant groups. The weak period of residence effects in the study of self-employment is in contrast to the strong effects of this factor on immigrant wages, particularly in the U.S. (see, for example, Chiswick (1978)). One possible explanation is that wage/salary employment is the immigrants' preferred state and the barriers to entry into this state (e.g., discrimination) are reduced with length of residence in the destination country. Such a pattern would be consistent with selfemployment offering an alternative to unemployment for those facing difficulties in wage/salary employment. That is, self-employment for some may be at last resort. Evans and Leighton (1989), for example, argue that self-employment is a refuge for "misfits",

11 The broad pattern for male non-English speaking immigrants is similar to that reported for female immigrants from third-world countries by Evans (1984). 
such as unemployed workers or those who have changed their jobs frequently.

Within the U.S. literature, a different approach to analysing the impact of period of residence on self-employment probabilities was undertaken by Borjas (1986). In line with the main theme of much of his research on immigrants, Borjas distinguishes the impact of period of residence from cohort quality effect. The results show that period of residence has a positive and significant impact on immigrants' self-employment choice. Moreover, it is shown that the quality effect associated with changes in the composition of cohorts also significantly influences the self-employment rates of immigrants, with more recently arrived cohorts having a higher propensity to be self-employed than earlier cohorts. Overall, Borjas' study highlights the importance of separating period of residence and cohort quality effects in studies of the self-employment experience of immigrants.

The above results suggest there may be a positive correlation between the time spent in the labour market and accumulation of skills, though it is possible that this is capturing financial capital effects rather than human capital effects. An alternative index of an individual's accumulated lifetime learning is age. Calvo and Wellisz (1980), for example, suggest that individuals acquire managerial skills through learning, and age might be superior to labour market experience as an indicator of this learning process. In line with the suggestion above that experience may capture financial considerations, Kidd (1993) argues that age is an index of accumulation of capital. Moreover, age may be a proxy for an individual's attitude towards risk, with mature-age persons being unwilling to bear the stress and risks associated with self-employment, while those who are in their early working years might be more willing to take on that risk. Studies that include an age variable in the model of self-employment (e.g. Brock and Evans (1986), Rees and Shah (1986), Borjas and Bronars (1989), Kidd (1993), as described in Table 3) generally report a significant and non-linear relationship with the propensity to be self-employed, with rates of self-employment increasing, at least initially, with age. These results are consistent 
with the findings associated with the labour market experience variable. ${ }^{12}$

In summary, the labour market experience variables reviewed in this section are assumed in the literature to impact on self-employment largely through their effect on the individual's managerial and learning abilities. The empirical research shows that there is a strong statistical association between the likelihood of a person being self-employed and their level of labour market experience. However, the work by Bernhardt (1994) that includes variables for financial capital in the estimating equation casts some doubt upon this explanation. Labour market experience, like education, may have a more minor role to play in the determination of self-employment status once account is taken of financial constraints.

\section{Other Individual and Family Background Characteristics}

While economists focus on the impacts of 'traditional' variables such as education, experience and age on the self-employment choice, other factors such as the internal locus of control' and family background are predominantly studied by psychologists and, - to a lesser extent, sociologists. These factors have also been considered by those economists who have attempted to specify a more encompassing model of selfemployment choice. Relevant empirical findings are listed in Table 4.

12 Note that studies typically include in their analysis two of the three variables: age, labour force experience and education. Because labour force experience is generally not directly available in most data sets, it is constructed from information on age and education. In this regard the debate between Blinder (1976) and Rosenzweig and Morgan (1976) on the relative merits of age and experience in wage equations is relevant. 
Table 4: Individual Characteristics, Family Background and Self-Employment Propensity

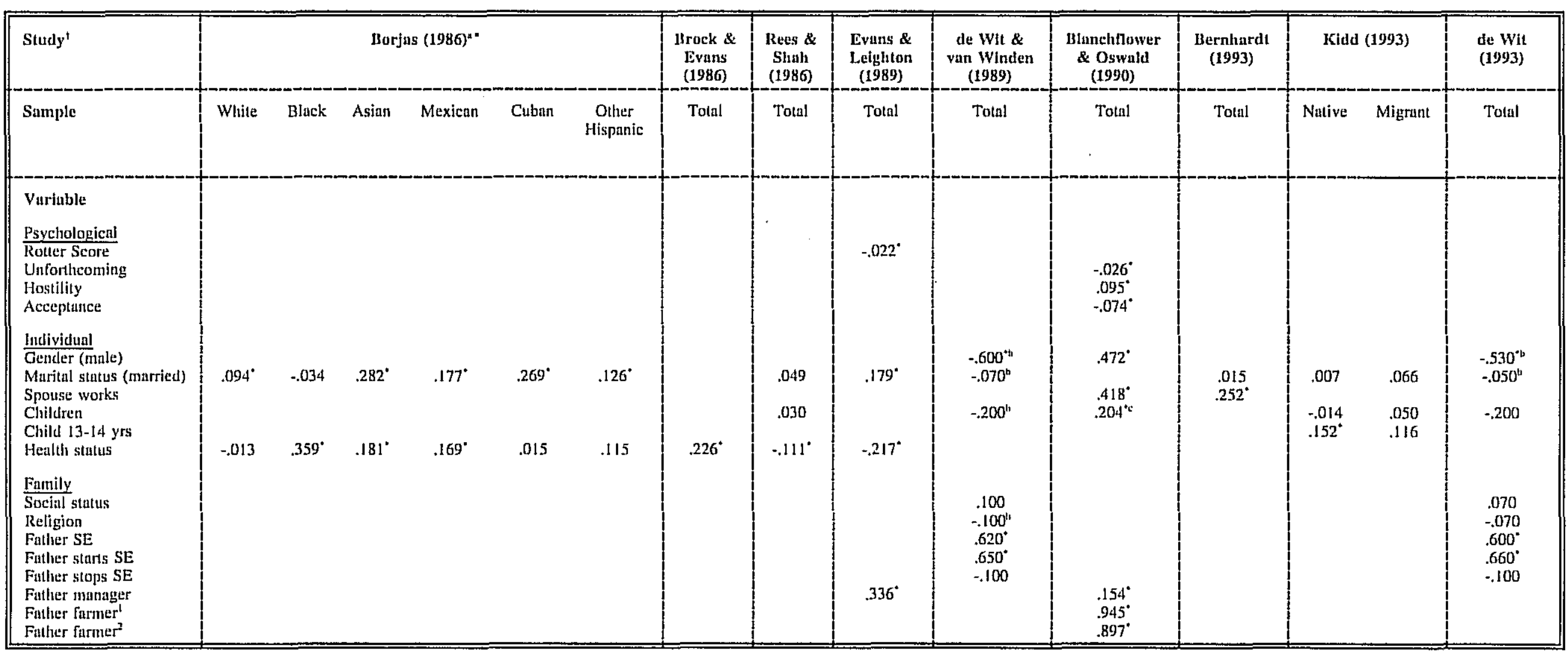

Note: ${ }^{*}$ " See Table 2. "Marital Status $=1$ if not married; Unforthcoming = unforthcomingness syndrome; Hostility = hostility to children syndrome; Acceptance = anxiety for acceptance syndrome; Gender $=1$ if female; Religion $=$ not Roman Catholic; Children $=1$ if no children. ${ }^{\mathrm{C}}$ Children $=1$ if has children. Farmer ${ }^{1}=$ hires employees; Farmer ${ }^{2}=$ no employees; $\mathrm{SE}=$ Self-employment. 
It is assumed that individuals who possess a high level of 'internal locus of control' are those willing to take charge of their own future. This trait is often associated with motivation or 'entrepreneurial drive', which encourages self-employment. Evans and Leighton (1989) test this influence using an instrument called the Rotter test. ${ }^{13}$ A higher value on this test is associated with lower perceived levels of control over one's destiny and hence there should be a negative relationship with the propensity to be self-employed. Evans and Leighton report a significant negative effect for this variable. Hence, individuals who possess an 'internal locus of control' (i.e., a relatively low Rotter score) are more likely to be self-employed. Blanchflower and Oswald (1990) also indicated that psychological factors that appear to be associated with the individual's 'entrepreneurial drive' play significant roles in self-employment. Thus, the self-employed were less likely than average (as children) to be anxious for acceptance or unforthcoming, and more likely than average to show hostility to other children.

Some authors (e.g., de Wit and van Winden (1989) and de Wit (1993)) have used family background variables such as social status and religious beliefs as indirect measures of psychological factors, the individual's 'need for achievement' or 'internal locus of control' beliefs. As shown in Table 4, these variables are generally not significant determinants of the propensity to be self-employed. This suggests that either family background is not an appropriate proxy of the person's psyche, or that these family background variables also capture other influences on self-employment choice which operate in the opposite direction to the psychological factors. Many of these alternative influences of family background have been examined in models of self-employment in the sociology literature.

13 The standard Rotter test consists of an internal-external scale. This is a measure of perceived 'locus of control', where the individual believes he/she is in charge of his/her destiny (internal), or it is determined by forces beyond his/her control (external). The test comprises a number of questions, and two choices (reflecting intemal and extemal beliefs) are provided for each question. The respondent is asked to select the choice he/she believes to be true. The Rotter score is calculated as the total number of external choices made by the respondent (Rotter (1982)). The Rotter test score may be related to personal, social, or cultural variables (Pandey and Tewary (1979)). 
With respect to the other influences that the family background variables may. capture, most discussion has centred on the individual's acquisition of cultural values. According to the Cultural Orthodox approach in the sociology literature (see Light (1984)), the family unit serves as the channel through which cultural values can be passed to the individual. In empirical work, one of the most important family background factors in this regard is the labour force status of the person's father (see Table 4). It is generally argued that an individual is likely to follow his/her father into self-employment because the psychological barrier towards this status is reduced, or he/she may take over the family business once the father has retired.

The impact of family background variables on the propensity to be self-employed can be tested in a number of ways. Regarding the father's occupational status, Evans and Leighton (1989) and Blanchflower and Oswald (1990) found that individuals are more likely to be self-employed if their fathers are managers or farmers, and less likely to choose this employment status if their fathers are unskilled. Studies by de Wit and van Winden (1989) and de Wit (1993), based on employment outcomes for 1983, included dummy variables indicating whether the father was self-employed in 1952, or the father started or stopped self-employment at a later stage (between 1952 and 1958). Both studies reported that the individual's propensity to be self-employed is enhanced if his father was self-employed or started self-employment at a later stage. However, if the father had stopped being self-employed, this had no significant impact on the individual's selfemployment decision. ${ }^{14}$

Therefore, family background (e.g., father's employment status) and the individual's psyche play significant roles in determining self-employment choice. Other individual characteristics which may be important in influencing an individual's employment choice

14 In addition, studies by Borjas and Bronars (1989) and Bernhardt (1994) used the mother's educational attainment as a measure of the quality of upbringing. This variable has a positive and significant effect on the individual's propensity to be self-employed. 
include gender, marital status, spouse's employment status, the number of children and health status. The impacts of these variables on self-employment choice are also presented in Table 4. Most of the empirical findings associated with these variables accord with intuition. Consider, for example, the results from the married variable. Marriage is assumed in the economics literature to represent stability and thus to provide a suitable background for risky self-employment. ${ }^{15}$ Borjas (1986) argued that self-employed persons are faced with the possibility that their employees will shirk on the job. This risk can be reduced if a person is married and has his/her partner working in the business. Allocation of labour within the family is optimal since both self-employed workers will have the same incentive - maximising family profit, thus solving the shirking problem. Collectively, a married couple can 'put up' more finance to start a business. With the financial support of a spouse, a married person may be more willing to take the risk and family support may make self-employment less demanding than it would otherwise be. All these factors would tend to provide a person with the means to enter into self-employment. Most of the empirical results confirmed that there exists a positive relationship between marital status and the propensity to be self-employed, though this relationship is often insignificant, suggesting that the influences discussed are relatively weak and that refinements to the marital status variable are necessary. Blanchflower and Oswald (1990) and Bernhardt $(1994)^{16}$ provide evidence on one such refinement. They report that having a spouse who works significantly increases the individual's propensity to be self-employed.

This section has predominantly examined hypotheses from the sociology literature. The results indicate that the psyche of an individual, the father's occupational status and the spouse's employment status are important determinants of self-employment outcomes.

15 It should be noted that the taxation effect for married couples may also be important in self-employment. As the majority of studies of self-employment have been cross-sectional, analysis of taxation issues has not received much attention. Blau's (1987) time-series evidence suggests that tax rates can influence the decision to become self-employed (see footnote 33).

16 Bemhardt (1994) also used this variable to reflect financial resources of the respondent. 


\section{Economic Conditions}

Inclusion of variables measuring economic conditions (e.g., unemployment) in the selfemployment model enables hypotheses from the sociology literature derived from Disadvantaged Theory and Reactive Cultural Theory to be tested. The impacts of economic factors on self-employment choice are presented in Table 5.

The Disadvantaged Theory assumes that self-employment is an alternative form of employment for disadvantaged (e.g., unemployed) individuals in the labour market. ${ }^{17}$ One view held by Evans and Leighton (1989) and Blanchflower and Oswald (1990) is that unemployment motivates an individual into self-employment. Thus, an individual who has been unemployed over a period of time may decide to become self-employed rather than continue to look for work in the wage/salary sector. Evans and Leighton reported that selfemployment is positively and significantly influenced by unemployment experience in the U.S. labour market, though unemployment is an insignificant regressor in Blanchflower and Oswald's study of the U.K. labour market. This may be due to the young age group in Blanchflower and Oswald's study. For these youths unemployment may not be important - because they can still rely on their family for financial support.

Table 5: Economic Conditions and Self-Employment Propensity

\begin{tabular}{|l|c|c|}
\hline Study $^{\dagger}$ & Evans \& Leighton (1989) & Blanchflower and Oswald (1990) \\
\hline Sample & Total & Total \\
\hline Variables & & \\
Unemployment & $.001^{* \mathrm{a}}$ & $-.001^{\mathrm{b}}$ \\
Number of jobs & $.014^{\mathrm{ab}}$ & $.121^{\mathrm{b}}$ \\
\hline
\end{tabular}

Note: "See Table 2. ${ }^{2}$ Unemployment $=$ weeks of unemployment; Number of jobs $=$ number of jobs/wage experience. ${ }^{b}$ Unemployment $=1$ if ever unemployed; Number of jobs $=$ number of jobs since leaving school.

17 An alternative view is held by Hakim (1989) who argued that unemployment is not a motivational factor in the individual's employment choice. Hakim's view is that the individual seeks self-employment because he/she has always wanted to do so. 
Another variable which is often used to measure the stability of an individual in the labour market is the frequency of job tumover. It is assumed that because they respond to their position in the labour market (the Reactive Cultural approach) individuals who change jobs frequently are more likely to enter into self-employment. The empirical evidence supports this hypothesis, with studies by Evans and Leighton (1989) and Blanchflower and Oswald (1990) reporting a positive and significant relationship between the number of jobs held and the propensity to be self-employed in the U.S. and U.K. labour markets respectively.

These studies show, therefore, that there is a firm empirical basis for many of the hypotheses relating to the influence of non-financial factors on a person's self-employment choice. In addition, it is evident from the various studies reviewed that some individuals may be self-employed because of the various barriers they face in gaining employment in the wage/salary sector. There are also barriers that may prevent a person who wants to be self-employed from obtaining that status. Chief among these is a liquidity constraint which is reviewed next.

\section{Financial Capital}

One of the main factors considered by economists in the economic theory of selfemployment is the financial constraints faced by an individual who wishes to establish a business (e.g., Evans and Jovanovic (1989)). The importance of this factor has been demonstrated in several empirical studies and the results are presented in Table 6. Blanchflower and Oswald (1990) claimed that the initial capital sometimes required to set up a self-employment enterprise is often obtained through accumulation, gifts, inheritances or loans. They found that inheritance is a significant source of start-up capital ${ }^{18}$ and that the relationship between the size of the inheritance and the propensity to be self-employed

18 This may arise because Blanchflower and Oswald's (1990) study is restricted to individuals under 23 years. These individuals may not have sufficient time in which to accumulate the capital needed to start a business. Hence, they will have to rely on inheritance as a possible source of start-up capital. 
is non-linear. For an inheritance up to $£ 12,000$ the probability of self-employment rises, but it declines beyond this amount. ${ }^{19}$ Studies undertaken for the Australian and Canadian labour markets by Kidd $(1993)^{20}$ and Bernhardt (1994) also reported that the availability of capital is a significant factor in models of self-employment. For example, Bernhardt employed three variables to measure financial resources: whether the respondent's wife works; whether or not the respondent owns his own home; and the availability of investment income. The impact of each of these variables was positive and significant.

Table 6: The Availability of Finance and Self-Employment Propensity

\begin{tabular}{|c|c|c|c|c|}
\hline Study ${ }^{\dagger}$ & Blanchflower and & \multicolumn{2}{|c|}{ Kidd (1993) } & Bernhardt (1994) \\
\hline Sample & Total & Native & Migrant & Total \\
\hline \multicolumn{5}{|l|}{ Variable or Proxy } \\
\hline Age (yrs) & & $.090^{\circ}$ & $.100^{\circ}$ & \\
\hline $\operatorname{Age}^{2}(y r s)$ & & $-.001^{\circ}$ & $-.001^{\circ}$ & \\
\hline Spouse works & & & & $.252^{\circ}$ \\
\hline Investment income (000s) & & & & $.018^{\circ}$ \\
\hline Home ownership & & & & $.273^{*}$ \\
\hline Inheritance (000s) & $.117^{\circ}$ & & & \\
\hline Inheritance ${ }^{?}$ & $-.004^{*}$ & & & \\
\hline
\end{tabular}

Note: ${ }^{*}$ See Table 2.

The importance of financial capital to the self-employment outcome has an interesting implication that has been noted by Bernhardt (1994). He suggests that liquidity constraints that are a barrier to self-employment may protect less productive workers in that sector.

19 Smeaton (1992) showed that inheritance of funds play a very small role in the entrepreneurial decision in the U.K. labour market. Loans and gifts are predominantly used to establish fimms requiring less than $£ 10,000$.

30 Kidd (1993) uses age as a proxy for the availability of capital. As argued previously, the available empirical evidence suggests that this may be a useful interpretation of the age effects. 


\section{Occupational Status}

One of the hypotheses from the Middleman Minorities Theory (see Blalock (1967), Bonacich (1973) and Bonacich and Modell (1980)) states that individuals' employment outcomes are determined by the work undertaken (e.g., occupations). Individuals often train for, and work in, occupations as employees before establishing their own business. To the extent that the experience or contacts gained in occupations differ, an individual's type of occupation will help determine the types of self-employment they can enter. A summary of relevant results is presented in Table 7.

Table 7: Occupational Status and Self-Employment Propensity

\begin{tabular}{|l|c|c|c||}
\hline \hline Study & Brock \& Evans (1986) & Evans (1989) & Evans \& Leighton (1989) \\
\hline Sample & Total & Migrant & Total \\
\hline Variable & & & \\
$\begin{array}{l}\text { Continuous } \\
\text { Occ status (1-100) }\end{array}$ & & $.020^{*}$ & \\
$\begin{array}{l}\text { Categorical } \\
\text { Agriculture } \\
\text { Sales/Hotel/Repairs } \\
\text { Craft } \\
\text { Managerial } \\
\text { Professional }\end{array}$ & $.927^{\circ}$ & & $1.909^{\circ}$ \\
\hline
\end{tabular}

Note: ${ }^{\dagger \mathbf{a}^{*}}$ See Table 2.

Occupational or industrial status can enter the model either as dummy variables (e.g., Brock and Evans (1989), Evans and Leighton (1989)) or as a continuous, socioeconomic index of status attainment (e.g., Evans (1989)). Studies using the dummy variable approach have established that individuals employed in agriculture, sales, hotel, repairs, craft, managerial or professional occupations have a relatively high propensity to be selfemployed. For example, Brock and Evans found that compared to those employed as machine operators, individuals working in sales are more likely to be self-employed. This may be simply due to the nature of the work. Occupations such as sales and repairs are 
suitable for contracting-out and hence self-employment opportunities are available. In Evans' study, occupational status positively influences the individual's chances of being self-employed. ${ }^{21}$ Therefore, these results are consistent with the Middleman Minorities hypothesis.

The factors reviewed above affect the propensities of both the native bom and immigrants to be self-employed. However, other variables such as period of residence (reviewed earlier) and dominant language proficiency will typically influence the propensity of being self-employed among immigrants only. These variables may be used to test another hypothesis from the Middleman Minorities Theory, namely that immigrants (sojoumers) have little or no incentive to integrate into the general community and this may influence their employment choice. There has been only one study, however, of the links between English proficiency and self-employment choice: Evans (1989) shows that lack of fluency in the host country's language reduces the chances of an immigrant being self-employed.

Other variables, such as race and ethnic enclaves, may affect the employment outcomes of both immigrants and the native bom, but might be expected to have a more intense impact on the labour performance of immigrants. These variables have been considered in a number of studies and relevant empirical findings are reviewed below.

\section{Race}

One of the factors considered in the Reactive Cultural approach and Waldinger's (1986) theory of immigrant enterprise is the degree of discrimination against immigrants. One way of examining this is to focus on the choices different racial groups face. Different racial groups may be subjected to different degrees of employer and consumer

21 Perhaps the trade off is the change of sign for the impact of education in the model of self-employment. When Evans (1989) estimated an alternative model of self-employment where the occupational status variable was omitted, education had a positive influence on the propensity to be self-employed. However, when the core model is estimated with an occupational status variable, educational attainment has a negative impact on the propensity to be self-employed, as reported in Table 2. 
discrimination which may affect their employment decisions. For example, it is often thought that, for reasons associated with discrimination, non-Whites find it more difficult to enter certain occupations. However, it is not clear whether being self-employed in certain occupations will be easier for them relative to being wage/salary employed. Nor it is clear whether the strength of the racial effect would be the same for all groups.

The effect of race on the propensity to be self-employed differs appreciably across the studies by Rees and Shah (1986) for the U.K. labour market, and Brock and Evans (1986) and Borjas and Bronars (1989) for the U.S. labour market ${ }^{27}$. Thus, non-Whites have a lower probability of self-employment in the U.K. labour market and, according to Brock and Evans (1986), a higher probability of self-employment in the U.S. labour market. There is little difference in the predicted ceteris paribus probabilities of self-employment for Whites, Blacks and Hispanics in the U.S. labour market, though Asians are more likely to be self-employed than other racial groups. These variations in findings across studies may be due to differences in the construction of the variables and methodology. The race coefficient in Rees and Shah's study picks up minority groups such as East African Asians and West Indians, whereas "Black" in the U.S. studies essentially picks up the Black American population and excludes Asians. These different racial groups may possess different propensities to be self-employed.

The Table 8 findings show, therefore, that membership of an identifiable group can affect the individual's employment type. The small number of studies examining this issue contrasts with the large volume of literature on racial differences in wages and unemployment outcomes. However, the group membership theme has been developed in the literature through research into whether it is the individual characteristics or some aspect of the group that the person is a member of that is important in this regard. A study of group characteristics concludes the review of the reduced-form studies.

22 The samples analysed consist of both immigrants and the native born. 
Table 8: Race and Self-Employment Propensity

\begin{tabular}{|c|c|c|c|c|c|c|}
\hline \multirow{2}{*}{$\begin{array}{l}\text { Study }^{\dagger} \\
\text { Sample }\end{array}$} & \multirow{2}{*}{$\begin{array}{c}\text { Brock \& Evans } \\
(1986)\end{array}$} & \multirow{2}{*}{$\begin{array}{c}\begin{array}{c}\text { Rees \& Shah } \\
(1986)\end{array} \\
\text { Total }\end{array}$} & \multicolumn{4}{|c|}{ Borjas \& Bronars (1989) ${ }^{\mathrm{a}}$} \\
\hline & & & White & Black & Asian & Hispanic \\
\hline \multicolumn{7}{|l|}{ Variable } \\
\hline Race & & $-.245^{\mathrm{b}}$ & .118 & .105 & .154 & .120 \\
\hline Black & $.428^{* b}$ & & & & & \\
\hline
\end{tabular}

Note: + See Table 2. a Figures for the Borjas and Bronars (1989) study are predicted probabilities formed using the characteristics of ethnic groups and the regression coefficients of Whites. ${ }^{b}$ Race $=1$ if the individual is non-White; Black $=1$ if the individual is Black.

\section{Group Characteristics}

Group membership may affect an individual's choice between self-employment and wage/salary employment. The main such characteristic in the literature on self-employment is ethnic enclaves. It has been argued that immigrants are more likely to be self-employed if there is an established ethnic market. This provides immigrants with potential customers as well as access to labour supply and capital. Hence, there are many channels through which ethnic enclaves can influence immigrants' propensity to be self-employed. These may be captured through inclusion of an enclave variable in the self-employment equation, and they will be discussed with reference to the work of Borjas (1986) and Evans (1989).

Before the role of ethnic enclaves in self-employment can be addressed, a brief comment on the creation of enclaves is required. The measurements of enclaves in empirical work are predominantly based on place of work or place of residence. The common approach is to apply residential agglomeration to define ethnic neighbourhoods (the number of people from the same ethnic background residing in a particular area). This is the approach used by both Borjas (1986) and Evans (1989).

Borjas (1986) argued that immigrants (e.g., Mexicans, Cubans) create enclaves by concentrating in specific geographical areas. He measured ethnic enclave size as the 
fraction of the Standard Metropolitan Statistical Areas' population that is Hispanic. In addition, Borjas separated the Hispanic sample into several sub-samples and conducted the same analysis with alternative definitions of ethnic enclaves. These specifications are: percent Cubans; percent Mexicans; and percent other Hispanics. Borjas concluded that Hispanics are more likely to be self-employed in areas which have a large Hispanic population. Moreover, the enclave effect on the propensity to be self-employed is larger for immigrants than for the ethnic native born, and this difference is significant in all Hispanic samples. This suggests that language (and/or culture) plays an important role in creating ethnic enclaves which in turn influences the propensity of immigrants to be selfemployed.

One study which considers enclave creation in the Australian labour market is Evans (1989). Evans canvassed a number of influences that group membership might have on the employment outcome and tested them using her so-called "group size" and "isolated labour pool" hypotheses (see Table 9). In order to test these hypotheses, Evans (1989) also adopted a surrogate measure based on the individual's birthplace and language. In this study ethnic group was defined with reference to the respondent's native country. However, if the respondent's native country is part of a larger set of countries that share a language, then all countries in this set were assumed to form the ethnic group. Ethnic group size is the number of persons of all ages in the respondent's ethnic group and is set to zero for immigrants from English-speaking countries. This ethnic group size variable was used to identify potential market size. However, this approach is insensitive to the size of the neighbourhood in which the group resides. For example, an immigrant group of ten persons residing in an area with a population of fifty persons will have a different effect from the same group of immigrants residing in an area with a population of 500 persons. 
Table 9: Residential Concentration and the Creation of Ethnic Enclaves: A Summary

\begin{tabular}{||l|l|l|}
\hline Study/Sample & Measure of Ethnic Enclaves & SE Effect \\
\hline $\begin{array}{l}\text { Borjas (1986) } \\
\text { Males aged 18-64 }\end{array}$ & $\begin{array}{l}\text { Percentage of the Standard Metropolitan } \\
\text { Statistical Areas' population that is } \\
\text { Hispanics: percent Mexican, percent Cuban; } \\
\text { and percent other Hispanic. }\end{array}$ & Positive \\
\hline $\begin{array}{l}\text { Evans (1989) } \\
\text { Male immigrants aged 16-64 }\end{array}$ & $\begin{array}{l}\text { Immigrant concentration by ethnic origin } \\
\text { and language: ethnic group size (the number } \\
\text { of persons of all ages in the respondent's } \\
\text { ethnic group); percent who speak English } \\
\text { 'not well' or 'not at all' in the respondent's } \\
\text { ethnic group. }\end{array}$ & Positive \\
\hline
\end{tabular}

A second measurement of ethnic enclave employed by Evans (1989) is the percent in Australia who speak English 'not well' or 'not at all' among adults aged 15 and over in the respondent's ethnic group. This approach has several drawbacks, including its neglect of the composition of the neighbourhood where the immigrant groups reside and its failure to take into consideration concentration of immigrant groups in one location. A further argument against using the approach proposed by Evans is that the hypothesis is based on the notion that lack of English proficiency influences the propensity to be self-employed rather than an immigrant's share of a common language. Despite these deficiencies the two measures for ethnic enclave in Evans' (1989) study have positive and significant impacts on the propensity to be self-employed. Thus, immigrants belonging to a large ethnic group are more likely to be self-employed than those belonging to a smaller ethnic group. Immigrants belonging an ethnic group with a large percent of individuals lacking in English proficiency are more likely to choose self-employment compared to immigrants where no member of the ethnic group lacks English fluency.

Thus, the importance of ethnic enclaves to the prospects of self-employment among immigrants have been demonstrated by Evans (1989) for the Australian labour market and Borjas (1986) for the U.S. labour market. These studies, however, are limited in number and, in the case of Evans' (1989) study, the measurement of ethnic enclaves is based on 
questionable assumptions. Nevertheless, the theoretical rationale for inclusion of enclave variables and the results to date suggest this is a fruitful area for further research.

In summary, the reduced-form studies of self-employment have examined several hypotheses regarding the importance of individual, family background, job-specific, economic and group determinants of employment choice. Gaining an overall perspective is made a little difficult by the tendency for each study to adopt a different specification of the estimating equation (1). Each study has, understandably, tailored its specification to the data set analysed. However, the weight of the evidence suggests that the individual's age, family background (particularly where the father was self-employed), the spouse's employment status, economic conditions, the availability of finance, occupational status and group (ethnic enclaves) membership are important determinants of the propensity of an individual to be self-employed. Several findings (e.g., those associated with period of residence) are consistent with Evans and Leighton's (1989) suggestion that selfemployment is a refuge for disadvantaged groups. Given the broad range of factors that significantly affect the self-employment outcome, Evans and Leighton's (1989) suggestion that economic approaches to modelling be expanded to include considerations from the sociology literature has support.

\subsection{The Structural Self-Employment Equation}

The earnings differential between self-employment and wage/salary employment plays an important role in theories of employment choice that place emphasis on monetary considerations. It is assumed that an individual will choose self-employment if he/she perceives the earnings in that status to be sufficiently greater (the earnings differential needs to outweigh any psychic costs) than from wage/salary employment. This hypothesis may be tested using a structural self-employment model..$^{23}$ Relatively few studies have

23 In estimating the structural equation, values for the earnings in the altemative employment states must be obtained. These are usually computed as predicted values from earnings equations estimated on separate samples of wage/salary earners and the self-employed. Such estimations must take account of the possibility that individuals may select themselves into a particular employment status because they have 
estimated the structural equation of self-employment. The major studies available are Rees and Shah (1986), de Wit and van Winden (1989), de Wit (1993) and Bernhardt (1994).

There are three findings of note from this group of studies. First, there is evidence from the estimation of the wage equations used to generate the earnings differential term that provides indirect information on the role of barriers to entry into self-employment. The second finding concerns the extent to which the results reviewed above from the reducedform model carry across to this alternative approach to estimation. The third outcome relates to the role of the earnings differential between self-employment and wage/salary employment. Details relevant to each of these three sets of findings are examined in this section.

The evidence on sample selection obtained from the estimation of wage equations is quite diverse. The sample selection correction term included in the wage equation for the selfemployed was statistically insignificant in the studies by Rees and Shah (1986), de Wit and van Winden (1989) and de Wit (1993). Bernhardt's study shows that the coefficient for selection bias is sensitive to model specification. When wealth was controlled for in the equation used to compute the sample selectivity term, Bernhardt found there was negative selection into self-employment. However, when wealth was not included in the selection equation, there was positive selection (significant at the 10 percent level) into self-employment. As wealth is a significant regressor in the selection equation, there is a preference for the former findings of negative selection.

It is worth noting that while the coefficients on the selection terms for the self-employed in the studies by Rees and Shah (1986), de Wit and van Winden (1989) and de Wit (1993)

comparative advantage (e.g., those with relatively high managerial ability will choose self-employment). In this situation estimation of the earnings equations for the self-employed and wage/salary employed by Ordinary Least Squares may yield biased and inconsistent estimates of population parameters. This problem is referred to as self-selection bias. To overcome this problem, researchers have used Heckman's (1979) two stage procedure. 
are statistically insignificant, the point estimates are consistent with negative selection. This negative selection implies that individuals may be forced into this sector by disadvantages in wage/salary employment or are motivated by factors other than pecuniary gains. Hence, it can be argued that these findings are consistent with the disadvantaged theory of sociologists (see also Evans and Leighton (1989)).

With regard to the effects of 'traditional' variables (education, labour market experience, father's occupation and financial capital) on the propensity to be self-employed, the results are similar to those in the reduced-form model. For example, with respect to educational attainment, Rees and Shah (1986) show that it has a positive and significant impact on the propensity to be self-employed (Rees and Shah do not control for occupation of employment in the self-employment equation). Likewise, the results from Rees and Shah also show that the age coefficients for the structural equation are similar to those in the reduced-form model, with the relationship between age and the propensity to be selfemployed being non-linear. The results from Bernhardt (1994) show that the availability of capital has a positive and significant impact on the self-employment outcome in both reduced-form and structural models. These findings indicate the robustness of these variables across model specification.

The third finding from the studies reviewed is the impact of the earnings differential on the propensity to be self-employed. The general finding is that this variable has a positive impact on the self-employment outcome (see Table 10). However, the degree of significance varies, depending on model specification. For example, Bernhardt (1994) found relative earnings to be highly significant (t-statistic $=9.99$ ) whereas the Rees and Shah (1986) study reported a lower level of significance (t-statistic $=1.82$ ). While the estimated effect of the relative earnings variable is positive in de Wit and van Winden's (1989) study, it is statistically insignificant ( $t$-statistic $=1.33$ ). This range of findings may 
follow from the different identifying restrictions used ${ }^{2+}$. For example, father's employment status variables are used to identify the self-employment equation in the studies by de Wit and van Winden (1989) and de Wit (1993), a variable for the number of children is used for this purpose in the study by Rees and Shah (1986), while variables for whether the spouse works, investment income and home ownership are used to identify the self-employment equation in the research by Bernhardt (1994).

Table 10: The Earnings Differential and Self-Employment Propensity

\begin{tabular}{||l|c|c|c|c||}
\hline Study ${ }^{\dagger}$ & $\begin{array}{c}\text { Rees \& Shah } \\
(\mathbf{1 9 8 6})\end{array}$ & $\begin{array}{c}\text { de Wit \& van Winden } \\
(\mathbf{1 9 8 9 )}\end{array}$ & de Wit (1993) & Bernhardt (1994) \\
\hline Sample & Total & Total & Total & Total \\
\hline $\begin{array}{l}\text { Variable } \\
\text { Eamings Differential }\end{array}$ & $.365^{\circ}$ & 0.200 & .020 & $3.600^{\circ}$ \\
\hline
\end{tabular}

Note: $\quad$ " See Table 2.

There are a number of concerns with this approach which may explain the mixed findings. First, the earnings data used for the self-employed may be quite poor. These data usually include asset income as well as labour market income and do not distinguish between business earnings and individual earnings (where the difference is retained earnings). Second, the emphasis in the models on pecuniary benefits may be misplaced. Nonmonetary incentives (e.g., the need for achievement) may be more important in this regard. Such factors are emphasised in the psychology literature where each individual has a set of needs and satisfying these needs becomes his/her goals (see Maslow (1954), McGregor (1960) and McClelland (1961)). For example, if the individual has a high need for achievement then he/she may select self-employment over wage/salary employment to satisfy this need. Third, the earnings variable used in the equation is the difference in

24 To identify the structural self-employment equation, some variables in this equation are not included in the eamings function. Similarly, for identification purposes, there needs to be at least one variable in the structural eamings equation that is not in the structural self-employment equation. Unfortunately, there is no economic theory to determine which variables should be excluded from the various equations, and the available studies have differed considerably in their approach to this issue. 
current earnings between self-employment and wage/salary employment. This implies that the individual is making a decision about sector of employment in each time period. An alternative earnings measure is the difference in present values of the earnings streams in the two employment sectors. If choice is based on the difference in present values, and the empirical model includes only the difference in current earnings, then the estimating equation is misspecified. It can be shown (see Willis and Rosen (1979)) that two relevant variables are omitted from the structural model, namely the growth rates in earnings in the two employment types, and the estimates will, in general, be biased and inconsistent.

These empirical matters are quite important and have not been resolved. Until there is progress in this direction, there seems good reasons for the literature's preference for reduced-form models.

From this brief review of the cross-sectional studies, it would appear that there is a need for greater attention to the measurement of the key pecuniary benefit variable in the structural model and that the evidence from the reduced-form models should be favoured over that obtained from structural models at this stage. This evidence provides information on the relative importance of a range of factors (e.g., age, family background, availability of financial capital, economic conditions) to the individual's employment decision at any one point in time. There is a need for further research using data sets that contain information on financial capital in order to ascertain whether the strong effects associated with labour market experience in studies that do not control for financial constraints are a reflection only of this misspecification. And there is an obvious need for further work on the relationship between group membership (e.g., racial, birthplace) and the propensity to be self-employed, both at the individual and group level. Research along these lines using cross-section data has the potential to significantly advance our understanding of the determinants of self-employment choice. However, cross-sectional analyses are subject to a number of weaknesses such as omitted individual-specific fixed effects and dynamics that can be accommodated using longitudinal data. It is of interest, therefore, to establish the 
extent to which the findings surveyed above carry over to analyses of longitudinal data.

\section{Longitudinal Analyses}

The studies examined in the above section have estimated models of self-employment using cross-sectional data. Attempts to use these models to predict changes in selfemployment rates over time are unlikely to be fully successful, however, as they will miss out on any dynamics associated with self-employment choice. This limitation is addressed by several studies using longitudinal data. The studies which will be reviewed from this perspective are Blau (1987), Evans and Jovanovic (1989), Evans and Leighton (1989), Bates (1990) and Blanchflower and Meyer (1992). ${ }^{25}$ The focus of each of these studies differs. The emphasis in Blau's study of the U.S. labour market is on changes in the industrial structure, relative prices of technology, rising marginal tax rates, wage rigidity and rising real retirement benefit. ${ }^{26}$ Evans and Jovanovic also study the U.S. labour market and focus mainly on the validity of liquidity constraints. In comparison, Evans and Leighton look at the roles of expected earnings, psychological factors and liquidity constraints. The focus of Bates' study was to determine the empirical relevance of Lucas' - (1978) hypothesis on managerial ability and entrepreneurship ${ }^{27}$, and Jovanovic's (1982) hypothesis regarding individual's learning ability and business survival. ${ }^{28}$ Finally, the focus in the study by Blanchflower and Meyer was the transition of Australian and American youth (age 16-25 years) from wage/salary employment into self-employment. ${ }^{29}$

Blau's (1987) study differs from the others in that he focused on estimating the trend towards selfemployment for the U.S. labour market over the period 1948-82. Hence, time series data are used. Results will, however, be included in this section for convenience.

27 This hypothesis assumes that those who remain self-employed possess relatively greater managerial skills compared to those who do not survive.

28 This hypothesis assumes that those who remain self-employed possess greater leaming skills compared to those who do not survive.

29 Because of the age group under consideration, the study must be interpreted with care as the propensity to become self-employed is not expected to be very high due to the sample's limited labour market experience and inadequate financial capital. Moreover, the relationship between the transition into self- 
The empirical evidence will be presented in two stages. The first stage reports on the transition from wage/salary employment into self-employment. The second stage reports factors which enhance the individual's business survival rate.

\subsection{The Transition into Self-Employment}

The determinants of employment choice that are emphasised in longitudinal studies of self-employment are similar to those discussed in cross-sectional analyses. Among these are educational attainment, labour market experience, liquidity constraints and wage rates.

\section{Educational Attainment and Job-Related Characteristics}

The first variable to be considered is educational attainment. From Table 11 it can be seen that, unlike the conflicting results obtained in cross-section studies, this variable is generally insignificant in longitudinal-based studies. While this finding may be due to the time element introduced into the study with the use of longitudinal data, it is more likely due to the correlation between educational attainment and financial capital (Bates (1990)). Studies which included both variables (e.g., Evans and Jovanovic (1989), and Evans and - Leighton (1989)) have reported insignificant education coefficients. ${ }^{30}$ In comparison, Blanchflower and Meyer's (1992) study, which did not control for financial capital, recorded a positive and significant relationship between years of education and the transition into self-employment for the U.S. labour market.

employment and individual characteristics may be volatile as the 16-25 year age group is characterised by considerable 'job-shopping'.

30 Bemhardt's (1994) cross-sectional study, for example, included both education and capital variables in the self-employment model and found the former to be statistically insignificant. 
Table 11: Educational Attainment, Employment-Related Characteristics and the Transition into Self-Employment

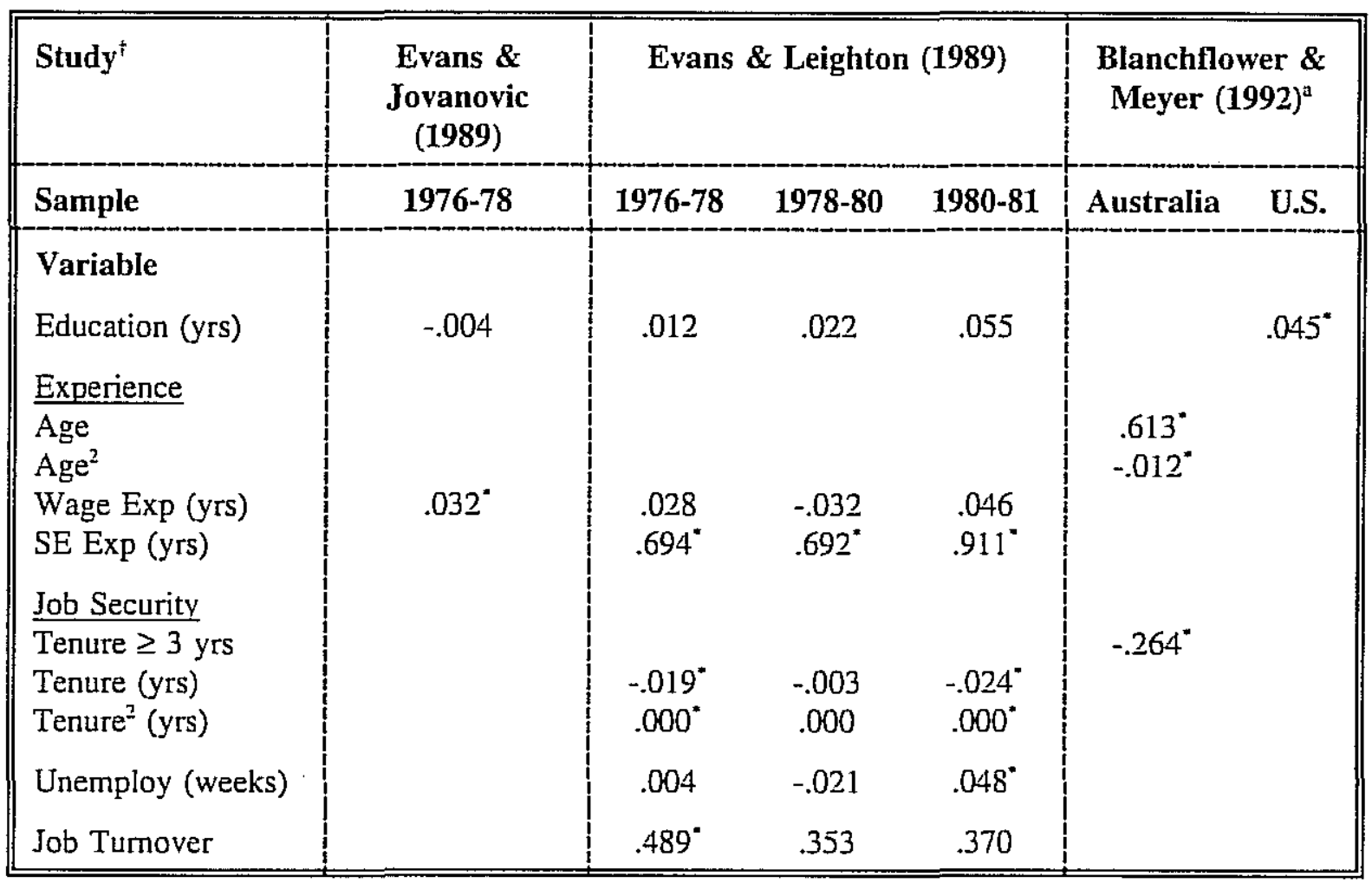

Note: ${ }^{+}$See Table 2. ${ }^{*}$ The U.S. specification contains different variables to the Australian specification.

A variable which has proven to be significant in determining the individual's propensity to switch from wage/salary employment into self-employment is labour market experience (see Table 11). Blanchflower and Meyer (1992), using age and 'age-squared', found that the transition into self-employment is significantly influenced by labour market experience for youth in the Australian labour market. Mixed results are reported, however, when more refined measures of labour market experience are used. For example, Evans and Leighton (1989) reported that previous experience in the wage/salary sector is insignificant, while previous self-employment experience had a positive and significant impact on the transition into self-employment. This is consistent with Jovanovic's (1982) proposition that individuals are able to learn from past experiences and experience accumulated in the selfemployment sector will be more useful to their employment decisions. In contrast, Evans and Jovanovic (1989) reported that the coefficient on previous wage/salary experience is 
positive and significant, though they did not consider self-employment experience. The general theme from these results, therefore, is that experience affects employment choice, and that experience accumulated in the self-employment sector is particularly relevant in explaining the transition into that sector. ${ }^{31}$

Other job-specific characteristics (e.g., job security) and employment-related characteristics, such as unemployment and the frequency of job turnover, which have significant impacts on the transition into self-employment are summarised in Table 11.

\section{Financial Capital and Income}

Several longitudinal studies of self-employment, namely Evans and Jovanovic (1989) and Evans and Leighton (1989), have tested the importance of the availability of capital. Net family assets were used to represent the net worth of an individual. Both studies report that the relationship between family net worth and the transition into self-employment is non-linear (Table 12). Initially, an increase of the individual's net worth increases his propensity to enter into self-employment. However, beyond a certain level, an increase in - net worth reduces entry into this employment status. There are several explanations for this non-linear relationship. First, as wealth increases, the importance of any initial constraint diminishes, ${ }^{32}$ though the impact in this regard is relatively more important at low levels of wealth. Second, it might be the case that as an individual's net wealth increases, the degree of risk aversion rises. Because self-employment is assumed to be risky, this may deter entry into this employment status.

31 Note that the importance of experience to the self-employment outcome holds in models that control for financial capital constraints. This contrasts with Bernhardt's (1994) finding from a cross-sectional analysis.

32 To further test this hypothesis, Evans and Jovanovic (1989) examined entrepreneurial selection under liquidity constraints. The major finding is that there are binding capital constraints on business start-up. If there is no constraint, the probability of becoming self-employed would increase to 5.11 percent from 3.81 percent. Evans and Jovanovic concluded that liquidity constraints deter 1.30 percent of the population from trying self-employment. 
Table 12: Financial Capital, Income, Taxation and the Transition into Self-

Employment

\begin{tabular}{|c|c|c|c|c|c|c|c|c|}
\hline \multirow{2}{*}{$\begin{array}{l}\text { Study }^{\dagger} \\
\text { Sample }\end{array}$} & \multicolumn{3}{|c|}{ Blau $(1987)^{d}$} & \multirow{2}{*}{$\begin{array}{c}\begin{array}{c}\text { Evans \& } \\
\text { Jovanovic } \\
(1989)\end{array} \\
1976-78\end{array}$} & \multicolumn{3}{|c|}{ Evans \& Leighton (1989) } & \multirow{2}{*}{$\begin{array}{c}\begin{array}{c}\text { Blanchflower } \\
\text { \& Meyer } \\
\text { (1992) }\end{array} \\
\text { U.S. }\end{array}$} \\
\hline & $\mathrm{SE}^{\mathrm{a}}$ & $\mathrm{SE}^{\mathrm{b}}$ & $\mathrm{SE}^{\mathrm{c}}$ & & 1976-78 & 1978-80 & $1980-81$ & \\
\hline \multicolumn{9}{|l|}{ Variable } \\
\hline \\
\hline$\overline{\text { Asset }}$ & & & & $.008^{\circ}$ & $.079^{\circ}$ & $.061^{\circ}$ & $.099^{\circ}$ & \\
\hline Asset $^{2}$ & & & & $-.002^{\circ}$ & -.002 & $-.001^{\circ}$ & $-.001^{*}$ & \\
\hline \multicolumn{9}{|l|}{ Eamings } \\
\hline$\overline{\text { Income }}$ & & & & $-.022^{\circ}$ & -.003 & -.261 & $-.516^{\circ}$ & $-.118^{\circ}$ \\
\hline Income $e^{2}$ & & & & & .015 & .033 & .066 & \\
\hline Min wage & $-.019^{\circ}$ & $.025^{\circ}$ & $-.015^{*}$ & & & & & \\
\hline \multicolumn{9}{|l|}{ Taxation $^{c}$} \\
\hline$\overline{\text { Income }^{1}}$ & $-.137^{*}$ & $-.140^{\circ}$ & $-.185^{\circ}$ & & & & & \\
\hline Income $^{h}$ & $.156^{\circ}$ & $.186^{\circ}$ & $.169^{\circ}$ & & & & & \\
\hline
\end{tabular}

Note: " See Table 2. "The dependent variable is defined as the fraction of the labour force that is self-employed. 'The dependent variable is defined as the fraction of the labour force that has any earnings from self-employment. ${ }^{c}$ The dependent variable is defined as the fraction of the labour force that is self-employed only. " Blau (1987) used Ordinary Least Squares. " $\mathrm{TR}=$ tax rate; Income $^{\prime}=$ low income; and Income $^{\mathrm{k}}=$ high income.

An individual's earnings may also influence entry into self-employment, and its effects can be derived through variables for personal income or the minimum wage (Table 12). Studies by Evans and Jovanovic (1989), Evans and Leighton (1989) and Blanchflower and Meyer (1992) found that individuals with relatively low wages are more likely to switch into self-employment. ${ }^{33}$ Blau (1987) found the relationship between the minimum wage and entry into self-employment to be conflicting, with the estimated coefficients being negative for two out of three self-employment categories. A positive impact had been expected due to the minimum wages, as a form of wage rigidity, reducing employment

33 One study which controls for the impact of the tax rate on self-employment entry is Blau (1987). Here, the marginal tax rates under the personal income and payroll taxes are used. These combined tax rates are calculated from two annual income levels in each year: $\$ 7,000$ (low income); and $\$ 17,000$ (high income). The positive coefficients of tax rate for the high income level is consistent with the hypothesis proposed by Long (1982), namely that an increasing tax rate makes it more attractive to engage in tax evasion tactics which are easier under self-employment than wage/salary employment. 
opportunities in the wage/salary sector. A negative coefficient may imply that the minimum wage serves as a safety net in the wage/salary sector, hence discouraging individuals from entering self-employment where such security is not available. Alternatively, this variable may be a crude proxy for wage rigidity.

The impacts of a number of other variables have been analysed in longitudinal studies, including marital status and occupational status. These will not be reviewed in detail here. However, it is noted that in the case of marital status, the estimated effect (negative and significant in longitudinal. studies) differs between cross-sectional data and longitudinal data. In contrast, the estimated effect of occupational status remains the same across types of analysis with individuals employed in manual jobs (e.g., construction) possessing a higher propensity to be self-employed than those working in administrative jobs (e.g., clerical), suggesting that these findings, in addition to those associated with the availability of finance, are quite robust.

\subsection{Exit from Self-Employment}

- Once individuals have entered into self-employment their survival depends on a number of factors, such as learning ability and the continual availability of capital. Only a few studies have estimated the individual's probability of remaining self-employed. This may be due to the lack of data or to the fact that the literature in this area is relatively new. Examples of this approach are Evans and Leighton (1989) and Bates (1990). With respect to this aspect of self-employment, the empirical literature provides information on two general issues. The first of these is the element of time. The second is the impact of individual characteristics on survival rates in self-employment.

\section{The Element of Time}

Evans and Leighton (1989) and Bates (1990) assume that survival in self-employment is time dependent. This follows Jovanovic's (1982) theory on how the individual gradually learns of his/her managerial ability over time and reassesses his/her employment position 
at the end of each period. Evans and Leighton thus estimated survival and hazard rates for the self-employed as a function of either age or labour market experience. ${ }^{34}$ Bates regressed the probability of surviving in business on industrial and family characteristics and two time variables. Both studies reported that the longer the length of time in selfemployment, the more likely are individuals to remain in this sector (Table 13). Bates suggested the reason for this is that individuals who survived in self-employment possess greater business acumen, labour market skills and access to financial capital compared to those who do not survive.

Table 13: The Survival and Hazard Rates in Self-Employment

\begin{tabular}{|c|c|c|c|}
\hline Study & \multicolumn{2}{|c|}{ Evans \& Leighton (1989) } & Bates $(1990)^{b}$ \\
\hline Sample & \multicolumn{2}{|c|}{$1961-1981$} & 1976-1982 \\
\hline Variable & $\frac{\text { Survival Rate }}{\text { (Percent) }}$ & $\frac{\text { Hazard Rate }}{\text { (Percent) }}$ & Hazard Rate \\
\hline Self-employed (yrs) & & & \\
\hline 2 & 79.4 & 10.3 & \\
\hline 4 & 61.5 & 11.3 & \\
\hline 6 & 51.4 & 8.20 & \\
\hline 8 & 47.0 & 4.30 & \\
\hline 10 & 41.2 & 6.20 & \\
\hline 12 & 39.9 & 1.60 & \\
\hline 14 & 39.9 & 0.00 & \\
\hline Time $80^{c}$ & & & $-.307^{*}$ \\
\hline Time $82^{c}$ & & & $-.399^{*}$ \\
\hline
\end{tabular}

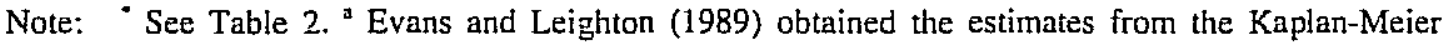
procedure. "Bates (1990) used a logit estimation procedure. ${ }^{\text {" Time } 80}=1$ if the business was started during 1980 or 1981 ; Time82 = 1 if the business was started during 1982. As all members of Bates' sample were self-employed in 1982, his time coefficients are akin to hazard rates.

\section{Individual Abilities}

The only study to link covariates to the survival rate in self-employment appears to be Bates (1990). His study examines the role of educational attainment, managerial

34 Evans and Leighton (1989) controlled for heterogeneity. 
experience and age. Results are displayed in Table 14. The findings for educational attainment, which offers one proxy for the individual's abilities, are consistent with the proposition advanced by Lucas (1978) and Calvo and Wellisz (1980), namely individuals with higher levels of education are those who possess better managerial and learning abilities which may improve their business success.

Table 14: Individual Abilities and Business Longevity

\begin{tabular}{|l|c|}
\hline Study & Bates (1990) \\
\hline Sample & $1976-1982$ \\
\hline Variable & \\
Educational Attainment & \\
\hline High school education & $.108^{\circ}$ \\
1 year of college & $.084^{\circ}$ \\
4 years of college & $.252^{\circ}$ \\
5 + years of college & $.307^{\circ}$ \\
Managerial experience & -.026 \\
Age & .027 \\
\hline 35 - 44 years & $.092^{*}$ \\
45 - 54 years & -.041 \\
$55+$ years & \\
\hline
\end{tabular}

Note: ${ }^{-}$See Table 2. ${ }^{a}$ The method of estimation is logit.

Managerial ability can also be enhanced through managerial experience. ${ }^{35}$ Surprisingly, the estimated coefficient on a managerial experience variable was insignificant in Bates' research, which is in contrast to Lucas' (1978) theory. This may be due to the narrow definition of the experience variable (see footnote 35). Age of the business owner is assumed to be related to business survival in a non-linear fashion. Bates found that owners between the ages of 45 and 54 were most likely to survive in self-employment. In comparison, owners aged 55 and over were less likely to survive. This finding is consistent with Calvo and Wellisz's (1980) proposition that managerial ability is

35 Bates (1990), defines managerial experience as experience acquired in a managerial capacity prior to owning a business. 
influenced by the individual's learning capacity and age over time. Hence, if everyone has the same learning capacity, older persons will be more productive and efficient and, as a result, are more likely to succeed. However, as a person becomes older, his/her ability tó grasp the new technology diminishes and this causes the negative relationship between individuals in the older age group $(55+$ years) and business longevity.

While few in number, the longitudinal studies reviewed here permit the transition into self-employment and the probability of success in that state to be studied, and complement the cross-sectional studies that provide information on the determinants of the allocation of the labour force to self-employment and wage/salary employment at one point in time. Overall, the empirical findings regarding conventional variables such as liquidity constraints and occupational status are consistent across both types of studies. However, the longitudinal studies show that the individual's probability of remaining self-employed depends not only on the number of years spent in the business, but his/her ability as well. This is consistent with Jovanovic's (1982) proposition relating to the revision of managerial ability over time and the proposition advanced by Calvo and Wellisz (1980) - regarding learning capacity. Other characteristics which explained the individual's survival included the availability of finance, a finding that supports Evans and Jovanovic's (1989) theory of liquidity constraints. The studies using longitudinal data reviewed provide valuable information on the dynamics associated with self-employment, thus addressing some of the deficiencies associated with cross-sectional studies.

\section{Conclusion}

Overall, the empirical evidence indicates that characteristics such as family background (e.g., father's self-employment status) occupational status and economic conditions are significant determinants of self-employment choice. The results from reduced-form and structural equations of self-employment presented in this review reveal that the estimated impacts of these variables vary little across model specifications. In other words, many of the empirical findings are robust. An examination of the findings from applied research 
based on longitudinal data reveals a set of variables whose estimated impacts do not vary between cross-sectional and longitudinal studies and a set of variables whose estimated effects are sensitive to the type of data used in the research. The coefficients which were identified as being the same across models include job security, unemployment experience, income and liquidity constraints. In comparison, the effects of educational attainment, labour market experience and marital status vary between cross-section and longitudinalbased studies. This may be due to the time element introduced into the model, differences in specification of the estimating equations or differences across studies in the construction of these variables. For example, the results for labour market experience are sensitive to the inclusion/exclusion of capital in the self-employment equation, and this varies across data sets. It appears that in cross-sectional studies the experience effect on selfemployment choice is only significant when capital is excluded from the self-employment equation. However, in longitudinal studies, the impact of labour market experience on the propensity to be self-employed is significant when capital is controlled for. With respect to the individual's chances of survival in self-employment, the time spent in self-employment and educational attainment have significant impacts.

In addition, there is a small but important set of studies that demonstrate that ethnic enclaves influence the self-employment choice of immigrant groups. These studies show that ethnic enclaves provide a market for self-employed immigrants where they can cater for other individuals from the same ethnic background. In this context, the segregation of immigrants from the general community encourages self-employment.

The empirical evidence is consistent with various economic and sociological theories of self-employment. For example, many studies reported positive and significant impacts of age on the propensity to be self-employed. This is consistent with the study by Calvo and Wellisz (1980) that focuses on relationship between learning and entrepreneurship. The impact of capital on the propensity to be self-employed is also positive and significant. This finding supports Evans and Jovanovic's (1989) hypothesis concerning the links 
between financial constraints and entrepreneurship. Regarding theories advanced in the sociology literature, the Middleman Minorities Theory and Cultural Theory are also supported by the empirical results. For example, the results reported for occupation variables suggest that the nature of the work has a significant influence on the selfemployment outcome. This is consistent with one aspect of the Middleman Minorities Theory. The Reactive Cultural Approach, which focuses on an individual's response to his/her current situation, was tested using the frequency of job turnover. The evidence of a positive relationship between job turnover and the propensity to be self-employed is consistent with this approach.

The empirical studies of self-employment, therefore, have provided a solid basis for understanding the determinants of this employment status. The structural models of selfemployment, the role of demand-side factors such as ethnic enclaves, the importance of financial capital, and differences in the propensity to be self-employed across groups (racial, immigrants), have been identified in the review as topics requiring further research. There is also a need for additional studies based on longitudinal data. Such research will complement the advances made in the theoretical literature and lead to a fuller understanding of self-employment choice across a range of labour markets. In pursuing these topics, researchers should be mindful that the range of factors that affect the propensity to be self-employed is not necessarily restricted to economic considerations. On this matter, we quote Evans and Leighton (1989, p.256), "The sociological and psychological literature on entrepreneurship contains many insights that economists might consider incorporating in their models". 


\section{REFERENCES}

Bates, T. (1990) "Entrepreneur Human Capital Inputs and Small Business Longevity", The Review of Economics and Statistics, Vol. 72, No. 4 (November), pp. 551-559.

Bernhardt, I. (1994) "Comparative Advantage in Self-Employment and Paid Work", Canadian Journal of Economics, Vol. 27, No. 2 (May), pp. 273-289.

Blalock, H.M. Jr. (1967) Toward a Theory of Minority-Group Relations, John Wiley \& Sons, New York.

Blanchflower, D.G. and B. Meyer (1992) "A Longitudinal Analysis of Young Entrepreneurs in Australia and the United States", in Youth in the Eighties, Papers from the Australian Longitudinal Survey Research Project, Edited by R.G. Gregory and T. Karmel, DEET and Centre for Economic Policy Research, Australian National University, Canberra, pp.63-96.

Blanchflower, D.G. and A. Oswald (1990) "What Makes a Young Entrepreneur?", Centre for Labour Economics, London School of Economics, Discussion Paper, No. 373 (January).

Blau, D.M. (1987) "A Time-Series Analysis of Self-Employment in the United States", Journal of Political Economy, Vol. 95, No. 3 (June), pp. 445-467.

Blinder, A.S. (1976) "On Dogmatism in Human Capital Theory", The Journal of Human Resources, Vol. 11, No. 1 (Winter), pp. 8-22.

Bonacich, E. (1973) "A Theory of Middleman Minorities", American Sociological Review, Vol. 38, No. 5 (October), pp. 583-594.

Bonacich, E. and J. Modell (1980) The Economic Basis of Ethnic Solidarity: Small Business in the Japanese American Community, University of California Press, Berkeley.

Borjas, G.J. (1986) "The Self-Employment Experience of Immigrants", The Journal of Human Resources, Vol. 21, No. 4 (Fall), pp. 485-506.

Borjas, G.J. and S.G. Bronars (1989) "Consumer Discrimination and Self-Employment", Journal of Political Economy, Vol. 97, No. 3 (June), pp. 581-605.

Brock, W.A. and D.S. Evans (1986) The Economics of Small Businesses: Their Role and Regulation in the U.S. Economy, Holmes \& Meier, New York.

Calvo, G.A. and S. Wellisz (1980) "Technology, Entrepreneurs, and Firm Size", Quarterly Journal of Economics, Vol. 95, No. 4 (December), pp. 663-677. 
Chiswick, B.R. (1978) "The Effect of Americanization on the Earnings of Foreign-born Men", Journal of Political Economy, Vol. 86, No. 5 (October), pp. 897-921.

de Wit, G. (1993a) Determinants of Self-Employment, Physica-Verlag, Heidelberg.

---- (1993b) "Models of Self-Employment in a Competitive Market", Journal of Economic Surveys, Vol. 7, No. 4, pp. 367-397.

de Wit, G. and F.A.A.M. van Winden (1989) "An Empirical Analysis of Self-Employment in the Netherlands", Small Business Economics, Vol. 1, No. 4, pp. 263-272.

Evans, M.D.R. (1984) "Immigrant Women in Australia: Resources, Family and Work", International Migration Review, Vol. 18, No. 4 (Winter), pp. 1063-1090.

---- (1989) "Immigrant Entrepreneurship: Effects of Ethnic Market Size and Isolated Labor Pool", American Sociological Review, Vol. 54, No. 6 (December), pp. 950962.

Evans, D.S. and B. Jovanovic (1989) "An Estimated Model of Entrepreneurial Choice Under Liquidity Constraints", Journal of Political Economy, Vol. 97, No. 4 (August), pp. 808-827.

Evans D.S. and L.S. Leighton (1989) "Some Empirical Aspects of Entrepreneurship", American Economic Review, Vol. 79, No. 3 (June), pp. 519-535.

Hakim, C. (1989) "New Recruits to Self-Employment in the 1980s", Employment Gazette, Vol. 97, No. 6 (June), pp. 286-297.

Heckman, J.J. (1979) "Sample Selection Bias as a Specification Error", Econometrica, Vol. 47, No. 1 (January), pp.153-161.

International Labour Office (1994) 1994 Yearbook of Labour Statistics, International Labour Office, Geneva.

---- (1995) 1995 Yearbook of Labour Statistics, International Labour Office, Geneva.

Jovanovic, B. (1982) "Selection and the Evolution of Industry", Econometrica, Vol. 50, No. 3 (May), pp. 649-670.

Kidd, M.P. (1993) "Immigrant Wage Differentials and the Role of Self-Employment in Australia", Australian Economic Papers, Vol. 32, No. 6 (June), pp. 92-115.

Light, I.H. (1984) "Immigrant and Ethnic Enterprise in North America", Ethnic and Racial Studies, Vol. 7, No. 2 (April), pp. 195-216.

Long, J.E. (1982) "The Income Tax and Self-Employment", National Tax Journal, Vol. 35, No. 1 (March), pp. 31-42. 
Lucas, R.E. Jr. (1978) "On the Size Distribution of Business Firms", Bell Journal of Economics, Vol. 9, No. 2 (Autumn), pp. 508-523.

McClelland, D.C. (1961) The Achieving Society, Von Nostrand, Princeton.

McGregor, D. (1960) The Human Side of Enterprise, McGraw-Hill, New York.

Maslow, A.H. (1954) Motivation and Personality, Harper, New York.

OECD Department of Economics and Statistics (1988) Labour Force Statistics: 19661986, OECD, Paris.

Pandey, J. and N.B. Tewary (1979) "Locus of Control and Achievement Values of Entrepreneurs", Journal of Occupational Psychology, Vol. 52, No. 2 (June), pp. 107-111.

Rees, H. and A. Shah (1986) "An Empirical Analysis of Self-Employment in the U.K.", Journal of Applied Econometrics, Vol. 1, pp. 95-108.

Rosenzweig, M.R. and J. Morgan (1976) "An Exchange: On the Appropriate Specification of Human Capital Models", The Journal of Human Resources, Vol. 11, No. 1 (Winter), pp. 3-7.

Rotter, J.B. (1982) The Development and Applications of Social Learning Theory: Selected Papers, Praeger, New York.

Smeaton, D. (1992) "Self Employment-Some Preliminary Findings", Centre for Economic Performance, London School of Economics, Discussion Paper, No. 96 (September).

United Nations, Department for Economic and Social Information and Policy Analysis (1996) 1994 Demographic Yearbook, United Nations, Geneva.

Veall, M.R. and K.F. Zimmermann (1996) "Pseudo-R ${ }^{2}$ Measures for Some Common Limited Dependent Variable Models", Journal of Economic Surveys, Vol. 10, No. 3 (September), pp. 241-259.

Waldinger, R.(1986) "Immigrant Enterprise, A Critique and Reformulation", Theory and Society, Vol. 15, No. 1-2, pp. 249-285.

Willis, R.J. and S. Rosen (1979) "Education and Self-selection", Journal of Political Economy, Vol. 87, No. 5, pt. 2, pp. S7-S36. 